\title{
Pengaruh Metode Story Telling melalui Pemanfaatan Program Power Point untuk Meningkatkan Kemampuan Mengenal Konsep Bilangan 1-10 pada Anak Usia Dini Manyaran Semarang
}

\section{Laila Nur Savitri}

Prodi Teknologi Pendidikan, Sekolah Tinggi Teknologi Nusantara Lampung

laila.savitri@gmail.com

Penelitian ini bertujuan untuk mengetahui (1) efektifitas metode bercerita dengan program power point untuk anak usia dini, (2) mengetahui perbedaan kelompok eksperimen dan kelompok kontrol. Pendekatan pada penelitian ini adalah kuantitatif Jenis penelitian adalah desain eksperimen dengan tehnik uji t (komparasi antara kelas eksperimen dengan kelas kontrol). Objek penelitian adalah 46 siswa kelompok A di TK PGRI 59 Manyaran. Uji coba instrumen dilakukan dengan uji reliabilitas antar rater dan analisis kuantitatif dilakukan dengan analisis uji t Independent Sample T Test. Hasil penelitian menunjukan bahwa: (1) Pembelajaran Metode Bercerita dengan Penggunaan Program Power Point sangat efektif dengan hasil observasi kelas Eksperimen mendapatkan hasil rata-rata lebih tinggi (kelas Eksperimen 0,974, kelas Kontrol 0,767). Ini menunjukkan bahwa metode penggunaan program power point lebih diminati anak TK dibanding pembelajaran sehari-hari. (2) perbedaan antara kelompok eksperimen dan kelompok kontrol sudah terbukti, hasil dari (mean) rata-rata kelompok eksperimen 49, 9167 dan kelompok kontrol 32,9583. Hal ini dibuktikan dari hasil output SPSS sebesar 8,998 (0,05). Hasil dari $\mathrm{P}$ value 0,03, jadi Pvalue $<0,05$. Pada derajat kebebasan 46 siswa $(0,05)$ pada tabel kritis T $(2,013)$. Dari hasil hitung 8,998 > 2,013. Ini menunjukan bahwa metode pembelajaran dengan penggunaan program power point di minati anak usia dini.

Kata Kunci: metode bercerita, efektifitas, program powerpoint

This study aims to determine (1) the effectiveness of storytelling method with power point program for early childhood, (2) to know the difference of the experimental group and the control group. Approach in this research is quantitative This research type is experimental design with $t$ test technique (comparison between experiment class and control class). The object of research is 46 students of group A in kindergarten PGRI 59 Manyaran. The test of the instrument was carried out with the average reliability test and the quantitative analysis was conducted by the independent $t$ test Sample T Test. The results showed that: (1) Learning Storytelling Method with the use of Power Point Program is very effective with the results of class observation Experiments get higher average results (experimental class 0.974, Control class 0.767). This shows that the use of power point program is more preferred for kindergarten children than daily learning. (2) the difference between the experimental group and the control group was proven, the result of the mean (mean) experimental group 49, 9167 and the control group 32,9583. This is evidenced from the output of SPSS of 8.998 (0.05). The result of $P$ value 0.03 , so Pvalue $<0.05$. On the degrees of freedom 46 students $(0.05)$ on the critical table $T$ (2.013). From the calculation of 8,998> 2,013. This shows that the method of learning with the use of power point program in early childhood interest..

Keywords: methods of storytelling, effectiveness, powerpoint program 


\section{PENDAHULUAN}

Usaha dalam pengertian di atas merupakan upaya pendidikan secara menyeluruh meliputi tiga kawasan pendidikan yaitu: kegiatan pengajaran, kegiatan latihan dan kegiatan bimbingan. Pendidikan merupakan usaha sadar yang terencana untuk mewujudkan suasana belajar dan proses pembelajaran agar peserta didik secara aktif mengembangkan potensi dirinya untuk memiliki kekuatan spiritual keagamaan,pengendalian diri, kepribadian,kecerdasan,ahlak mulia,serta ketrampilan yang diperlukan dirinya,masyarakat,bangsa dan negara.

Para ahli perkembangan anak bersepakat bahwa anak bukan seorang dewasa kecil karena hingga mencapai usia 15tahun,anak tidak dapat membuat alasan atas tindakannya seperti seorang dewasa. Informasi ini didasarkan pada karya Jean Piaget (Aisyah, 2008:5.3), seorang ahli perkembangan biologi yang mendedikasikan hidupnya untuk mengamati dan mencatat secara dekat kemampuan intelektual anak. Kita sering membuat kesalahan dengan mengharapkan anak berfikir seperti orang dewasa. Oleh karena itu, orang tua dan pendidik harus memahami apa yang diharapkan seorang anak secara realistis ketika dia berada masa perkembangannya menuju dewasa.

Menurut Hartati (Aisyah, 2008:15) anak usia dini memiliki karakteristik yang khas,diantaranya:(1) memiliki rasa ingin tahu yang besar,(2) merupakan pribadi yang unik,(3) suka berfantasi dan berimajinasi,(4) masa paling potensial untuk belajar,(5) menunjukkan sikap egosentris,(6) memiliki rentang daya konsentrasi yang pendek,(7) sebagai bagian dari mahluk sosial. Dari berbagai karakter anak usia dini guru mempunyai tugas yang sangat penting untuk menciptakan lingkungan belajar yang kondusif supaya anak didik dapat berkembang secara maksimal yang disini difokuskan pada kemampuan konsep bilangan yang didasarkan pada kemampuan kognitif pada anak.

Perkembangan kognitif terkait erat dengan perkembangan intelektual dan perkembangan mental. Perkembangan kognitif pada anak dipengaruhi berbagai faktor,di antaranya adalah kematangan fisik,pengalaman dan interaksi anak dan orang-orang di sekitarnya. Pengasuh dan pendidik anak perlu melakukan assesmen kognitif dengan mengamati dan melakukan pencatatan tentang aktivitas anak sehari-hari sehingga dapat memperoleh informasi tentang tahapan perkembangan kognitif dan belajar pada anak.

Fridana (2011) Teori perkembangan kognitif menyatakan bahwa pertumbuhan mental individu adalah bagian terpenting dalam perkembangan anak. Anak yang aspek kognitifnya berkembang baik, akan dapat mengembangkan proses berfikir,merespon objek di lingkungannya, dan merefleksikan pengalamannya. Seiring dengan kematangan anak, akan terjadi strukturisasi yang progresif dalam proses kognitif anak. Dalam peristiwa tersebut proses berfikir anak berkembang menjadi lebih kompleks. Keterampilan belajar pada anak terjadi melalui proses elaborasi di dalam otak (mind), bukan diluar otak.

\section{KAJIAN TEORI}

\section{Program Power Point}

Program Powerpoint adalah salah satu program yang digunakan untuk membuat slide atau presentasi yang memiliki berbagai kelebihan (Benny Pribadi, 2010:8.1). Fasilitas dalam powerpoint memiliki kelebihan yang menyebabkan program ini sering digunakan banyak orang dibanding program aplikasi yang lain.

Berbicara konsep bilangan pasti erat hubungannya dengan matematika. Pembelajaran matematika erat juga hubungannya dengan perkembangan kognitif pada anak usia dini. Pengertian dari Matematika adalah bahasa simbol tentang berbagai gagasan, Skemp (Tombokan Runtukahu, 2014:32). Lambang lambang matematika bersifat artifisial dan baru memiliki arti setelah sebuah makna di berikan kepadanya. Tanpa kebermaknaan matematika hanya sebuah kumpulan rumus-rumus yang mati. 
Pembelajaran matematika di TK di awali dari mengenal konsep terlebih dahulu dan permainan dengan menghitung, tetapi kegiatan tersebut bersifat pengenalan dan di lakukan dengan kegiatan yang menyenangkan dengan suasana yang gembira.

\section{Matematika Permulaan}

Beth \& Piaget Tombokan Runtukahu (2014) mengatakan bahwa yang dimaksud dengan matematika adalah pengetahuan yang berkaitan dengan berbagai struktur abstrak dan hubungan antar struktur tersebut sehingga terorganisasi dengan baik. Sementara Kline dalam (Tombokan Runtukahu,2014:28) mengatakan bahwa matematika adalah pengetahuan yang tidak berdiri sendiri, tetapi dapat membantu manusia untuk memahami dan memecahkan permasalahan sosial, ekonomi dan alam.

Kemampuan dasar matematika anak pra sekolah yang berada pada fase praoperasional diwarnai kemampuan berfikir secara simbolis.(Martini Jamaris, 2005:44).

Kemampuan konversi anak pada fase praoperasional dapat dibagi dalam beberapa tahap, diantaranya:(1) kemampuan memikirkan bahwa benda-benda tersebut dapat berubah sesuai dengan bentuk dan tempat dimana benda itu ditempatkan, (2) kemampuan mengembangkan ide, (3) kemampuan mempertahankan pendapatnya.(Martini Jamaris, 2005:44)

Kemampuan dasar matematika tidak hannya kesadaran terhadap hitungan dan tidak hannya mmenyangkut kemampuan untuk menghitung"satu,dua, dan seterusnya,,,,". Pemahaman untuk menghitung juga berhubungan dengan strategi dalam menghitung, seperti: hari ini ada empat anak bermain di area balok, menghitung kehadiran anak, memperkirakan berapa kali untuk melompat dan kegiatan sehari-hari dimasing-masing area.(Martini Jamaris,2005:45) Pembelajaran (kegiatan pengembangan) matematika di TK, seperti juga membaca dan menulis sebaiknya tidak diajarkan di TK, tetapi kegiatan pengembangan tersebut sebaiknya bersifat pengenalan dan dilakukan dalam kegiatan bermain dan dilakukan dengan gembira dan menyenangkan. Kegiatan pengembangan di TK senantiasa dilakukan melalui bermain dengan cara yang gembira dan menyenangkan. Hal ini sesuai dengan motto kegiatan pengembangan di TK,yaitu"bermain sambil belajar dan belajar seraya bermain".

Guru dapat memberikan beberapa contoh kegiatan belajar (permainan) matematika di TK: (1) mengelompokan dan menyortir berbagai benda. Kegiatan semacam ini sangat disukai oleh anak-anak usia TK. Kegiatan ini dapat dilakukan dengan cara meminta anak-anak mengumpulkan benda-benda yang ada disekitar TK atau sekitar rumah mereka, kegiatan ini anak menjadi semangat untuk menghitung benda yang di dapat, (2) mengenal angka melalui lagu dan syair atau sajak berirama. Lagu atau sajak sederhana merupakan media sederhana dan menyenangkan bagi anak untuk belajar sesuatu. Guru dapat menciptakan dan mengenalkan lagu-lagu atau sajak yang berirama dan yang bermuatan pengenalan dasar-dasar berhitung yang merupakan bagian dari matematika, seperti bilangan atau konsep penjumlahan sederhana, (3) bermain dengan sendiri, seorang anak akan senang sekali jika diajak mengukur tinggi badanya atau panjang langkahnya dengan menggunakan jengkal atau alat ukur berupa meteran. Sering dilakukan dalam pembelajaran anak senang jika megukur meja masing-masing, (4) bermain dengan kartu, kartu bergambar dengan benda-benda bergambar atau simbol dengan jumlah tertentu maupun kartu bertuliskan angka-angka dapat digunakan untuk mengenalkan konsep bilangan, penjumlahan dan pengurangan sederhana. Kegiatan permainan dapat divariasikan sesuai dengan situasi dan kondisi, (5) bermain melalui kegiatan merangkai, guru dapat mengenalkan anak-anak dengan berbagai ukuran dan perbandingan dengan menerapkan kegiatan merangkai. Pada kegiatan ini disediakan benda-benda atau gambar dengan ukuran berbeda-beda. Misalnya,benda yang pendek sampai yang panjang, kecil sampai yang besar, kurus sampai yang gemuk, caranya dengan meminta anak mengurutkan benda-benda tersebut dengan kriteria yang telah ditentukan, (6) bermain menghitung, kegiatan bermain menghitung ini dapat dilakukan dengan cara 
menghitung jarak dari satu titik ke titik yang lain. Hitungan dapat dilakukan dengan langkah, (7) bermain dengan bentuk-bentuk geometri

Kegiatan mencari jodohnya, misalnya anak disuruh memasangkan bentuk pada tempatnya dengan bentuk yang sama pula, untuk kegiatan ini guru harus menyediakan pola atau lubang berbentuk geometri. Dari pembahasan tentang pembelajaran matematika dalam belajar mengenal bilangan, guru juga dapat menerapkan bermacam-macam model pembelajaran. Model pembelajaran merupakan salah satu rancangan atau pola yang digunakan dalam salah satu menyusun kurikulum,kegiatan pembelajaran, mengatur materi yang diajarkan,dan memberikan petunjuk kapada guru untuk memilih metode yang tepat.

\section{METODE}

Jenis metode penelitian yang di pilih adalah metode Eksperimen yang diartikan sebagai metode penelitian yang digunakan untuk mencari pengaruh perlakuan tertentu terhadap yang lain dalam kondisi yang terkendalikan (Sugiyono, 2012:107). Penelitian eksperimen yang digunakan PosttestOnly Control Design, dimana subjek terdiri dari dua kelompok masing-masing dipilih secara random. Kelompok pertama diberi perlakuan (X) dan kelompok satunya tidak. Sedangkan pendekatan yang digunakan adalah kuantitatif, yaitu pendekatan yang mendasarkan pada perhitungan angka angka atau statistik. Metode kuantitatif dapat di artikan sebagai metode penelitian yang berlandaskan pada filsafat posivitisme, digunakan untuk meneliti pada populasi atau sempel tertentu.(Sugiyono, 2012:14). Perihal yang menjadi populasi dalam penelitian populasi 55 siswa dan sample menggunakan rumus slovin dengan taraf signifikansi 5\% (0,05). Pada penelitian ini, hanya menggunakan sebagian populasi untuk dijadikan sample. Penentuan pengambilan sampel menggunakan rumus slovin dengan taraf signifikansi 5\% dengan jumlah populasi 55 siswa. Teknik pengumpulan data menggunakan teknik observasi dengan melihat reliabilitas antar rater dengan hasil $\mathrm{rxx}^{\prime}=0,767$. Karena diatas 0,65 maka dapat disimpulkan reliabilitas antar rater sudah termasuk kategori baik.

\section{HASIL PENELITIAN}

\section{Deskripsi Objek Penelitian}

Deskripsi obyek penelitian berdasarkan kedua kelompok ,kelompok pertama adalah kelas Eksperimen dan kelompok kedua adalah kelas Kontrol. Kelas eksperimen adalah kelas yang dilakukan observasi menggunakan metode pembelajaran program power point. Subjek dari kelas eksperimen adalah kelompok A dan sebanyak 24 siswa. Kelas kontrol adalah kelas yang dilakukan observasi dengan menggunakan metode pembelajaran sehari-hari. Subjek dari kelas kontrol adalah kelompok A dan sebanyak 24 siswa.

Kelas Eksperimen: Kelas Eksperimen yang terdiri dari 24 siswa pada kelompok A di TK PGRI 59 Manyaran. Kelas Eksperimen dalam kegiatan pembelajaran menggunakan program Power Point untuk mengenalkan bilangan kepada siswa.

Dari hasil nilai observasi pada kelas Eksperimen, di hitung dengan rumus SPSS 17.0 , mendapatkan hasil sebagai berikut:

Tabel 1. Hasil statistik kelompok Eksperimen

One-Sample Statistics

\begin{tabular}{lllll}
\hline & $\mathrm{N}$ & Mean & Std. Deviation & Std. Error Mean \\
\hline NILAI & 24 & 49.9167 & 8.37136 & 1.70880 \\
\hline Eksperimen & 24 & 1.00 & $.000^{\mathrm{a}}$ & .000
\end{tabular}


Hasil group statistik kelompok Eksperimen dengan jumlah subjek 24 siswa dari penghitungan one Sample Statistics mendapatkan hasil dengan analisis (mean) rata-rata 49,9167 dengan standar deviasi 8,37136. Pada kelompok eksperimen dengan subjek 24 siswa pada hitungan statistik mendapatkan $\mathrm{t}$ hitung 29,212. Hasil dari observasi oleh guru kelas eksperimen mendapatkan skor bervariasi. Hasil skor akan di hitung dengan program SPSS 17.0. Penghitungan skor dengan Uji t.

Kelas Kontrol: Dari hasil nilai observasi kelompok kontrol dan dihitung dengan rumus SPSS 17.0, mendapatkan hasil sebagai berikut:

Tabel 2. Hasil statistik kelompok kontrol

One-Sample Statistics

\begin{tabular}{lllll}
\hline & $\mathrm{N}$ & Mean & Std. Deviation & Std. Error Mean \\
\hline Kontrol & 24 & 2.00 & $.000^{\mathrm{a}}$ & .000 \\
\hline NILAI & 24 & 32.9583 & 3.89514 & .79509
\end{tabular}

Hasil group statistik dari kelompok kontrol dengan jumlah subjek 24 siswa mendapatkan hasil dengan analisis (mean) rata-rata 32,9583 dengan standar deviasi 3,89514. Pada kelompok kontrol dengan subjek 24 siswa pada hiitungan statistik mendapatkan t hitung 41,451. Dari hasil perhitungan individual statistik antara kedua kelompok yaitu kelompok eksperimen dan kelompok kontrol mendapatkan hasil yang bervariasi.

Tabel 3. Perbedaan hasil uji normalitas

\begin{tabular}{llllll} 
No & Kelompok & Mean & T & SD & Sig (2 tailed) \\
\hline 1 & Eksperimen & 49,9167 & 29,212 & 8,37136 & .000 \\
\hline 2 & Kontrol & 32,9583 & 41,432 & 3,89514 & .000
\end{tabular}

\section{Hasil Analisis Data}

Uji t atau uji beda dimaksudkan untuk menguji perbedaan rata-rata hitung diantara kelompokkelompok tertentu yang memiliki persyaratan tertentu yang di teliti. Berdasarkan data di atas, apakah cukup bukti untuk mempercayai bahwa ada perbedaan pada kelompok kontrol dimana pembelajaran menggunakan metode sehari -hari dan pada kelompok eksperimen dimana pembelajaran menggunakan program power point.

Dari data hasil observasi diatas dilanjutkan dengan penghitungan melalui komputer dengan program SPSS 17.0 dan mendapatkan hasil hitung sebagai berikut:

Tabel 4. Hasil Independent Sample T Test

Group Statistics

\begin{tabular}{llllll}
\hline \multirow{2}{*}{ KILAI } & KELAS & N & Mean & $\begin{array}{l}\text { Std. } \\
\text { Deviation }\end{array}$ & Std. Error Mean \\
\cline { 2 - 6 } & Eksperimen & 24 & 49.9167 & 8.37136 & 1.70880 \\
\hline Kontrol & 24 & 32.9583 & 3.89514 & .79509
\end{tabular}


Hasil dari Group Statistik dengan jumlah subjek 48 siswa menyajikan hasil deskripsi variabel dengan analisis (mean) rata-rata nilai kelompok treatmen=49,9167 dengan setandar deviasi 8,37136 dan (mean) rata-rata nilai kelompok klasikal=32,9583 dengan setandar deviasi 3,89514. Hasil hitung ratarata pada kedua kelompok mendapatkan hasil rata-rata yang berbeda. Dilihat dari hasil out put pada kedua kelompok mendapatkan hasil (mean) rata-rata dan standar deviasi yang berbeda. Hasil hitung terlihat kelompok eksperimen lebih tinggi hasil (mean) rata-ratanya.

Tabel 5. Tabel hasil independent samples test

Independent Samples Test

\begin{tabular}{|c|c|c|c|c|}
\hline & & & NILAI & \\
\hline & & & $\begin{array}{l}\text { Equal } \\
\text { variances } \\
\text { assumed }\end{array}$ & $\begin{array}{l}\text { Equal variances } \\
\text { not assumed }\end{array}$ \\
\hline \multirow{2}{*}{\multicolumn{2}{|c|}{$\begin{array}{l}\text { Levene's Test for Equality } \\
\text { of Variances }\end{array}$}} & $\mathrm{F}$ & 9,528 & \\
\hline & & Sig. & ,003 & \\
\hline \multirow{7}{*}{$\begin{array}{l}\text { t-test for Equality of } \\
\text { Means }\end{array}$} & & $\mathrm{T}$ & 8,998 & 8,998 \\
\hline & & $\mathrm{df}$ & 46 & 32,513 \\
\hline & & $\begin{array}{ll}\text { Sig. } & (2- \\
\text { tailed }) & \end{array}$ & ,000 & ,000 \\
\hline & & $\begin{array}{l}\text { Mean } \\
\text { Difference }\end{array}$ & 16,95833 & 16,95833 \\
\hline & & $\begin{array}{l}\text { Std. Error } \\
\text { Difference }\end{array}$ & 1,88472 & 1,88472 \\
\hline & $95 \% \quad$ Confidence & Lower & 13,16459 & 13,12166 \\
\hline & $\begin{array}{l}\text { Interval of the } \\
\text { Difference }\end{array}$ & Upper & 20,75207 & 20,79500 \\
\hline
\end{tabular}

Pengujian (berdasarkan probabilitas/signifikansi) Ho dapat di terima jika $\mathrm{P}$ value $>0,05$ dan Ho di tolak jika $\mathrm{P}$ value $<0,05$. Hasil hitung menunjukkan bahwa nilai $\mathrm{P}$ value $0,003<0,05$ maka Ho di tolak dan Ha di terima.

Oleh karena nilai probabilitas (signifikansi) dengan equel variance not assumed ( di asumsikan kedua varian berbeda) 0,003 lebih kecil dari 0,05 maka Ha di terima, jadi dapat disimpulkan bahwa kedua varian berbeda ( varian kelompok eksperimen dan kelompok kontrol adalah beda). Dengan ini penggunaan uji t menggunakan equel variance not assumed (diasumsikan kedua varian berbeda).

Pada pengujian uji t menggunakan uji dua sisi dengan tingkat signifikansi $\alpha=5 \%$ atau 0,05 . Dari tabel di atas didapat nilai t hitung (equel variance not assumed) adalah 8,998. Tabel distribusi t dicari pada $\alpha=5 \%$ dengan derajat kebebasan (db) n-2 atau 48-2 = 46. Derajat kebebasan (db) 46 tidak ditemukan tabel kritis nilai-nilai t, sedang yang ada disekitar adalah db 40 dan 60 . Nilai kritis t pada db 40 pada taraf signifiksnsi $5 \%$ adalah 2,021, $1 \%$ sebesar 2,704 dan 0,1\% sebesar 3,551, sedang dengan db 60 pada taraf signifikansi $5 \%$ sebesar 2,000, $1 \%$ sebesar 2,660 dan 0,1\% sebesar 3,460. Karena db 46 lebih besar dari 40 lebih kecil dari pada 60 maka harus dilakukan interpolasi. Dari hasil di atas untuk perhitungan dapat dibagi dua jumlah db 40 dan db 60. Pada taraf signifikansi 5\% (2,021+2,000:2= $2,0105), 1 \%(2,704+2,660: 2=2,682$, dan $0,1 \%(3,551+3,460: 2=3,5055)$. Jadi, didapat hitung interpolasi pada taraf signifikansi $5 \%$ sebesar 2,0105, $1 \%$ sebesar 2,682 dan 0,1\% sebesar 3,5055.

Dari hasil penghitungan, nilai tabel (Tt) pada taraf signifikanssi $5 \%, 1 \%$, maupun $0,1 \%$ semuanya lebih kecil dari pada nilai t-observasi (to) atau to $>$ tt $0,1 \%>$ tt $1 \%>$ tt $5 \% \rightarrow$ to $=8,998>3,5055>$ 
$2,682>2,0105$. Dengan kata lain nilai $\mathrm{t}$ observasi lebih besar dari pada nilai t tabel pada taraf signifikansi $0,1 \%$.

Berdasarkan hitungan dari interpolasi dinyatakan bahwa nilai t observasi lebih besar dari nilai $t$ hitung pada interpolasi. Pada hitungan yang lain jumlah subjek 46 yang tidak ada pada tabel kritis t maka niali kritis t dapat dicari melalui tabel Ms Excel.

Secara keseluruhan rata-rata (mean) dari kedua kelompok mendapatkan hasil yang signifikan. Rata rata pada kelas eksperimen 49,9167 dengan standar deviasi 8,37134 sedangkan kelas kontrol rata-rata 32,9583 dengan standar deviasi 3,89514.

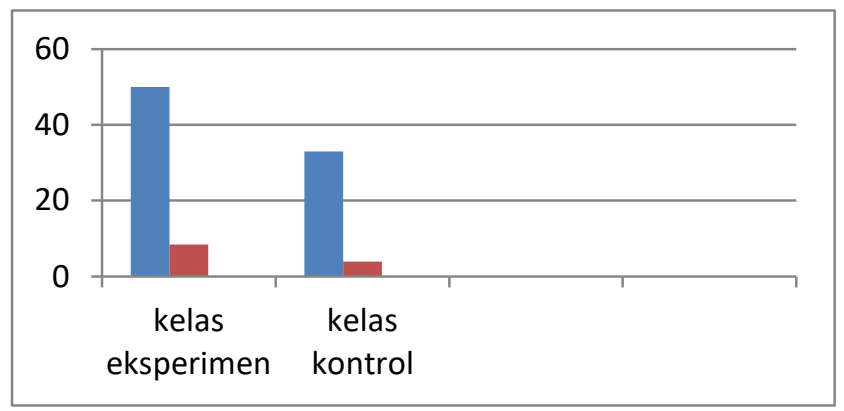

Gambar 1. Grafik mean dan standart deviasi

Dengan demikian nilai dari rata-rata metode pembelajaran pada TK PGRI 59 Manyaran mendapatkan hasil yang signifikan dan di kategorikan bahwa pembelajaran dengan pmenggunakan program power point lebih efektif. Hasil perbedaan pada kelompok eksperimen dan kontrol mulai dari hasil observasi dan hasil perhitungan uji t dapat di kategorikan baik karena pada kelompok eksperimen mendapatkan hasil yang lebih tinggi. Dengan hasil tersebut maka dapat diketahui bahwa metode pembelajaran di TK PGRI 59 Manyaran yang biasanya dilakukan dengan cara klasikal kurang efektif untuk mencapai tujuan pembelajaran yang maksimal. Karena itulah desain metode pembelajaran terhadap anak didik menjadi sebuah keharusan. Sehingga peningkatan kualitas kognitif anak tercapai dengan maksimal.

\section{DISKUSI}

Berdasarkan hasil hitung uji t melalui program SPSS 17.0 mendapatkan hasil yang signifikan Di dapat probabilitas/signifikansi pada $\mathrm{P}$ value $<0,05,(0,003<0,05)$. Dari hasil probabilitas/signifikansi $<$ dari 5\% maka Ho di tolak dan Ha di terima. Maka metode pembelajaran menggunakan program power point berhasil untuk dijadikan pembelajaran selanjutnya. Simpulan ini menunjukan bahwa kelompok eksperimen mengalami hasil yang lebih baik dibanding kelompok kontrol.

Tabel hasil perbandingan kelompok eksperimen dan kelompok kontrol

Tabel 6. Perbandingan hasil penelitian

\begin{tabular}{llll} 
No & Hasil & & Kelas \\
\hline & Analisis & Eksperimen & Kontrol \\
\hline 1 & $\Sigma \mathrm{R}$ & 1198 & 791 \\
\hline 2 & rxx & 0,974 & 0,767 \\
\hline 3 & Mean & 49,9167 & 32,9583 \\
\hline 4 & Std & 8,37136 & 3,89514 \\
\hline 5 & Uji t & 29,212 & 41,452
\end{tabular}


Hasil penelitian ini semakin mendukung bahwa metode pembelajaran khusunya di Taman KanakKanak merupakan bentuk pelaksanaan yang bertujuan membantu siswa mengenal, menumbuhkan dan mengembangkan diri, sikap dan kebiasaan belajar yang baik untuk menguasai pengetahuan dan ketrampilan sesuai program belajar disekolah. Penggunaan metode pembelajaran dengan pemanfaatan program power point cukup menentukan hasil yang maksimal pada pembelajaran di TK PGRI 59 Manyaran. Jika lembaga pendidikan memfasilitasi kegiatan seperti ini tidak menutup kemungkinan keberhasilan pembelajaran akan lebih baik.

Jika dibandingkan dengan penelitian yang dilakukan oleh Naili Rohmah pada bulan Oktober 2013, penelitian eksperimen dengan media "Dadu Aritmatika Sebagai Pengenalan Konsep Berhitung di Sentra Persiapan Kelas TK B". Tempat penelitian pada TK Siti Sulaechah 04 Semarang (Eksperimen) dan TK Labschool Unnes (Kontrol). Uji t pada kelompok Eksperimen mendapatkan hasil t hitung 15,387 sedangkan hasil uji t pada kelompok kontrol mendapatkan hasil t hitung 5,237. Berdasarkan hasil uji hipotesis menunjukkan hasil t hitung kelompok eksperimen lebih besar dari kelompok kontrol $(15,387>5,237)$. Kesimpulan ini menunjukan bahwa kelompok eksperimen mengalami peningkatan pengenalan konsep berhitung yang lebih tinggi di bandingkan dengan kelompok kontrol.

Dengan demikian, antara metode bercerita dengan pembelajaran sehari-hari atau klasikal dan melalui pemanfaatan program power point mendapatkan hasil yang signifikan. Dengan sebaliknya, jika guru menggunakan metode yang baik maka meminimkan kegagalan dalam penyampaian materi pembelajaran. Hipotesis awal; $\mathrm{Ha}=$ Terdapat perbedaan yang signifikan antara kelompok eksperimen dan kelompok kontrol. Ho = Tidak ada perbedaan yang signifikan antara kelompok eksperimen dan kelompok kontrol. Keputusan yang dapat diambil maka terlihat bahwa $\mathrm{t}$ hitung $>\mathrm{t}$ tabel $(8,998>2,013)$ dan $\mathrm{P}$ value $(0,003<0,05)$ maka Ho di tolak dan Ha di terima, artinya bahwa ada perbedaan yang signifikan antara kelompok eksperimen dan kelompok kontrol. Berarti metode pembelajaran dengan konsep pengenalan bilangan dengan metode eksperimen sangat signifikan di banding dengan kelompok kontrol.

\section{KESIMPULAN}

Dari hasil data penelitian diatas, ada beberapa kesimpulan dalam kaitannya hasil penelitian, antara lain adalah sebagai berikut: (1) hasil akhir penelitian lebih efektif kelas yang diberikan treatment dari pada kelas yang tidak diberikan treatmen.Melihat hasil uraian dan hasil penelitian bahwa pemanfaatan program power point pada taman kanak-kanak lebih efektif dibanding dengan metode pembelajaran sehari-hari; (2) dari perhitungan uji t (mean) rata-rata kelompok eksperimen mendapatkan hasil yang lebih baik $(49,9167)$ sedangkan kelompok kontrol mendapatkan hasil $(32,9583)$ dan nilai $\mathrm{P}$ value $(0,003<0,05)$. Kesimpulan ini menunjukan bahwa kelompok eksperimen lebih baik atau hasil dari t hitung kelompok eksperimen dan kelompok kontrol berbeda. Hasil dari perhitungan lebif efektif kelompok eksperimen dari pada kelompok kontrol dengan nilai mean eksperimen > dari nilai mean kontrol $(49,9167>32,9583)$.

\section{REFERENSI}

Aisyah, Siti.(2008). Jakarta: Perkembangan dan Konsep Dasar Pengembangan AUD. Universitas Terbuka.

Fridani, Lara \& Wulan, Sri.(2011). Jakarta: Evaluasi Perkembangan AUD. Universitas Terbuka.

Jamaris, Martini.(2005). Jakarta: Perkembangan dan Pengembangan Anak Usia Taman KanakKanak. Universitas Negeri Jakarta. 
Marzuki \& Gunawan \& Nurgiyantoro, Burhan.(2004). Yogyakarta: Statistik terapan. Gajah Mada University press.

Moeslichatoen, R.(2000). Malang: Metode Pengajaran di Taman Kanak-Kanak. Rineka Cipta.

Naili, Rohmah. (2013). Efektifitas Media Dadu Aritmatika sebagai Pengenalan Konsep Berhitung di Sentra Persiapan Kelas TK B Kota Semarang. Sekripsi, Semarang: Fakultas Ilmu Pendidikan Anak Usia Dini Universitas Negeri Semarang.

Pribadi, Benny A.(2010). Jakarta: Komputer dalam Kegiatan Pengembangan AUD. Universitas Terbuka.

Runtukahu J, Tombokan \& Kandou,Selpius.(2013). Yogyakarta: Pembelajaran Matematika Dasar Bagi Anak Berkesulitan Belajar. AR-RUZZ MEDIA.

Rusman. (2012). Bandung: Belajar dan Pembelajaran Berbasis Komputer. Alfabeta

Sugiyono. (2012). Bandung: Metode Penelitian Pendidikan Pendekatan Kuantitatif, Kualitatif , dan $R \& D$. Alfabeta.

Wibhowo, Christine.(2011). Jakarta: Stimulasi Kecerdasan Anak Menggunakan Teknologi Informatika. Gramedia. 